\title{
"Multiculturalism", Ethnic Tolerance, Non-Violence in the Republic of Kazakhstan
}

\section{Gizatullina GA*}

Department of Philology, Taraz state University, Republic of Kazakhstan

*Corresponding author: Gulgina Alimzhanovna Gizatullina, Associate Professor, Candidate of Philology, Taraz state University, Taraz city, Republic of Kazakhstan, Email: dafna_89@mail.ru

\section{Investigation Paper}

Volume 4 Issue 2

Received Date: April 03, 2021

Published Date: April 26, 2021

DOI: $10.23880 /$ abca-16000179

\section{Abstract}

The author conducts a comparative analysis of the policy of "multiculturalism" in Western Europe and the Republic of Kazakhstan, explaining why this policy is inhibited in Europe, while in Kazakhstan this policy is being successfully pursued. There are many reasons for this phenomenon, among which the author points to the historical roots of the tolerance of the Eurasian peoples who have experienced a common destiny, as well as the policy of "ethnic and confessional tolerance", which is based on the philosophy of non-violence. The author shows the origins of the philosophy of "non-violence", its historical forms of manifestation and the peculiarity of the practical development of the philosophy of "non-violence" in Kazakhstan. The practical implementation of the philosophy of "non-violence" is carried out thanks to the program documents of N. Nazarbayev.

Keywords: Multiculturalism; Tolerance; Non-Violence; Islamic Fundamentalism; Satyagraha Sabha; Polyconfessionalism; Secularism; Proletarian Internationalism

\section{Investigation Paper}

On November 15, 2010, a round table was held in Tehran on the topic "Eurasian policy of Kazakhstan in the context of the chairmanship in the OSCE". During the round table Murat Ismailov, Charge d'Affaires of the Republic of Kazakhstan in the Republic of Iran, noted that it would be more correct to talk about the OSCE's activities not so much about European security as about Eurasian security. Today it is impossible to ensure European security without the Asian dimension of security. In this regard, during its chairmanship in the OSCE, Kazakhstan tried in every possible way to initiate a new stage in relations between East and West and serve to strengthen mutual trust.

Mohammed Ali Najafi, vice-president of the Institute of Culture of the Organization for Economic Cooperation, noted that Kazakhstan responsibly approached the fulfillment of its duties as the OSCE chairman as a multinational and multi-confessional state. From the very beginning, the
Republic of Kazakhstan embarked on a course of using the rather powerful potential of the organization to effectively overcome nationalism, religious intolerance, and racism.

The Kazakhstan model of interreligious and interethnic harmony demonstrates to the whole world the boundless possibilities of the policy of "multiculturalism". The policy of "multiculturalism" was first tested in the USA and Canada. Multiculturalism is one of the aspects of tolerance, which consistsintherequirementfortheparallelexistence of cultures for the purpose of their mutual penetration, enrichment and development in the universal mainstream of mass culture. Initially, this policy was criticized in Western countries. Today, no government in Western European countries knows how to correctly build a policy of "multiculturalism". Neither the original path of French assimilation (immigrants must abandon their past customs and embrace the culture of the host country) nor the original Anglo-Saxon path of coexistence of different cultures does not work. The second way, even before Angela Merkel admitted it, seemed more 
a dream of idealists than a realistic and effective policy. Indeed, multiculturalism assumes that different the cultural communities present in a given territory are protected by relevant laws and self-governing in all respects that relate to the protection of the individual. Society as a whole is divided into many cultural communities, which, without fear of attack on their own traditions, will peacefully coexist. But such a society is hardly compatible with democracy. With very few exceptions, such societies can survive only as a result of very strong and undemocratic coercion. That is why the policy of multiculturalism is not suitable for European countries. Great Britain, Holland, Germany chose this path and was convinced of its unsuitability. There is a serious problem of the expansion of national cultures that are not ready to adapt to the local environment and create some kind of marginal spaces in Europe that are eating away at the European economy. The European Union now faces an urgent problem the consolidation of society, the strengthening of the position of the euro against the dollar and yuan and national cultural gaps create corrosion, including in the foundations of the European economy.

According to sociological studies, from 20 to $40 \%$ of Germans profess radical right-wing views. So $35.6 \%$ of Germans said that Germany is "dangerously overcrowded with migrants, and $34.3 \%$ that foreigners" come to Germany to profit from its social system. "As Angela Mergel stated, "The multi-stump politics is dead! We lied to ourselves for a long time when we invited guest workers that they would not stay here forever, that someday they would leave".

For the first time A. Mergel declared that German society is built on Christian values and those who reject this fact have no place here. The Chancellor called the fact that in a number of cities in the country the share of migrant children exceeds $60 \%$ as a threat to the well-being of Germany. She blamed the migrants themselves for the low level of education. Professor Elmar Brehler noted that the level of xenophobia is now lower than it was in the 50-60 years; however, the democratic system is in a threatening state. Young Germans, the most tolerant, demand strong power, and anti-Turkish and antiIslamic tendencies have become a characteristic feature of German xenophobia. The slightest excuse is enough for public opinion to explode, unleashing its anger on migrants.

The problem of greater or lesser ability to get along with new immigrants depends not on one, but on many factors: on the quality and rigidity of selection (immigration policy in a narrow sense), on economic cycles, on the ability to provide the necessary social services to working immigrants, on the ability to suppress illegal manifestations etc. But it also depends on the traditions of the country from which the immigrant came. There are immigrants who, thanks to the traditions of the country of origin, will be able to relatively easily find their place in the host country, and over time will assimilate in the French sense, if not they, then their children. Episodes of intolerance are and will be. But in general, many immigrants, especially from Eastern European countries, will be able to successfully enter Western European society.

But there are problems with Islam. The difficulties of understanding the representatives of different cultures, especially European and Islamic, were considered by Salman Rushdie in his "Satanic Poems". It is no coincidence that it is precisely about Muslims that they say when considering the failure of the policy of multiculturalism. What Europe is most afraid of is the excessive expansion of Muslim communities, not least because of the high birth rate, which will force European politicians to resort to tougher rules of coexistence in the European community. What can happen if two great, strong and proud civilizations, European and Islamic, have to coexist on the same territory?!

This depends partly on European politics, partly on the evolution of the Islamic world. If Islamic fundamentalism does not fizzle out in the foreseeable future, then Europe may not be up to the policy of peaceful coexistence of different cultures. If this rise of fundamentalism begins to gradually decline, then we will witness an unprecedented experiment - the introduction of Muslim immigrants to the rules of an open and free society.

Since gaining independence, tolerance in the religious sphere for Kazakhstan has become one of the central themes of preventing socio-political conflicts and building a modern civil society due to the established pluralism of religious associations [1].

The Republic of Kazakhstan has, in general, a reputation as a steadily progressing country in terms of the development of democracy and respect for human rights. In his last message Nazarbayev N, et al. [2] noted that the chairmanship of Kazakhstan in the OSCE will be held under the motto "Trust. Traditions. Transparency Tolerance".

Religious leaders could actively participate in solving political problems, although so far all these attempts have been unsuccessful. Western countries follow secularism, i.e. rejection of religious values. In theocratic states, religion dominates, but these countries cannot put forward initiatives, since they have discredited their policies.

A real chance appears for such energetically developing countries as Kazakhstan. The fact is that interest in traditional religions is growing in Kazakhstan and religiosity is growing. Ethnic tolerance is hidden behind religious tolerance. And ethnic tolerance is possible on the basis of a common Eurasian culture, common psychological stereotypes, which 
the Soviet government did not destroy, but preserved [1]. It should not be forgotten that ethnic tolerance is largely based on the philosophy of non-violence.

However, one of the pressing problems of the humanities is the huge gap between theory and practice. The proclaimed doctrines of humanism and non-violence remain only an appeal to philosophers and religious leaders, "with a voice crying in the wilderness." Two and a half thousand years ago, Siddhartthi Gautama Shakyamuni Buddha said, "Never in this world does hatred stop with hatred, but the absence of hatred stops it." Thus, he first proclaimed the principle of non-violence. However, most people believed that this principle was applicable only in interpersonal relationships. So, Mahatma Gandhi, considering the well-known ancient Indian term "ahimsa" not harming a living, considered it unsuccessful, since he did not convey an active and creative principle. And he replaced it with the term "satyagraha sabha" - resistance by non-violence. Applying the principle of "satyagraha sabha" in the struggle of the Indian people against the colonial rule of Great Britain, Gandhi achieved tremendous success.

The tactics and strategy of nonviolence were developed in the twentieth century by Tolstoy LN, Gandhi M, King ML, which was due to the following reasons:

- By the twentieth century, the humanization of public life is taking place, class, caste and class barriers are breaking, all people are equalized in the right to justice and happiness. Therefore, each person should build their relationships on the basis of non-violence.

- In the XX-XXI centuries, the scale of violence acquired an apocalyptic character. The global nature of conflicts and the destructive force of weapons have dispelled the last illusions about the possibility of using violence in the name of justice. While it was about limited, controlled violence, violence was seen as one of the many factors that determined the course and outcome of major events. However, the experience of the twentieth century with its destructive world wars and the danger of general death associated with nuclear weapons have radically changed the situation. Violence as an absolute evil has acquired a factual clarity.

However, it was precisely in the twentieth century that non-violence as a principle for solving political and social problems was used three times as an effective weapon. For the first time, Tolstoy LN. His appeal was picked up by Gandhi $M$ and successfully used in the struggle for the national independence of India.

A consistent and talented student of Gandhi was King ML. He developed nonviolent tactics in the fight for African American suffrage. In the course of the struggle, he managed to achieve his goal and today we are clearly contemplating the fruitful results of his tactics. African American Barack Obama became the President of the United States in 2008.

But despite such successful results of the ethics of nonviolence, it should be recognized that the truth of nonviolence is hardly implanted in consciousness and experience. This is largely due to the fact that the practice of non-violence is born in conditions of despair, the impossibility of solving socio-political problems. In addition, it is very difficult to follow the principles of non-violence in a world where for millennia all problems were solved with the help of violence.

Finally, the principle of nonviolence is a religious postulate. And the majority of mankind, thanks to atheism, abandoned religious values and do not follow them. The truth, however, is that in a situation of confronting social evil, a person's capabilities are not limited to the choice between obedience and violent challenge to injustice. There is a third way out of the confrontation - nonviolence. The metaphysics of nonviolence is based on the recognition of the divine, infinite being, with which visible earthly life is associated. The infinite beginning of all that exists is good. Therefore, all human deeds should be directed towards good.

The anthropology of non-violence proceeds from the contradictory nature of man, in which one can find the sublime and the base, the natural and the divine, the good and the evil, the natural and the social. Evil cannot distort a person in such a way as to deprive him of his right to life. Good in a person cannot be absolute in order to give him the right to judge someone else's life [3].

The meaning of the term "nonviolence" is not to do to a person what he does not want. Divine love flows from the content of this concept. Divine love means giving up narcissism and the desire to follow your will. Love for God presupposes not recognizing oneself as God and limiting one's activities, the ability to see one's own good in the good of others [3].

However, this deep philosophical content of the concept of "nonviolence" shows us how difficult it is to implement it in reality and those people who dare to follow the principle of "non-violence" impose a huge burden of responsibility on themselves. It is no coincidence that there are very few such political leaders acting within the framework of an ethic of non-violence. It is all the more gratifying that the first president of the Republic of Kazakhstan adheres to the ethics of non-violence in his foreign policy and socio-economic activities. It must be admitted that the ethics of nonviolence of Nazarbayev N, et al. [2] differs from the idea of nonviolence of Gandhi M and King ML. 
After all, she was born in different conditions. Unlike India, Kazakhstan did not have to fight for independence. However, the conditions for the formation of independent Kazakhstan were difficult and harsh. Integration ties were destroyed, factories did not work, and the national currency was unstable, agriculture collapsed. But none of Nazarbayev's team had the idea of blaming anyone for the difficult conditions. If all the former republics of the Soviet Union followed the path of genocide of the Russian-speaking population, blaming them for all their troubles and sorrows, then in Kazakhstan no one defiled the historical past.

All efforts of the Kazakh leader were aimed at restoring and stabilizing the economy in order to create favorable economic conditions for the life of the citizens of the republic. But for the economy to flourish, it was necessary to attract foreign investors. Foreign investors can work only in countries with developed legal institutions, civil society, and internally stable ones. To ensure internal stability in multinational and multi-confessional Kazakhstan, the principle of ethnic tolerance was proclaimed.

Ethnic tolerance has replaced the principle of proletarian internationalism. The principle of proletarian internationalism included two contradictory postulates:

- The flourishing of nations;

- The rapprochement of nations and the formation of a single community - the Soviet people. If the first postulate contributed to the development of national cultures, the formation of a national intelligentsia, then the second postulate leveled national languages, since it was believed that the Soviet people would speak Russian. Already during the December events of 1986, the ephemerality of this idea became clear. Therefore, the President of Kazakhstan proclaimed a new principle of peaceful coexistence of different peoples ethnic tolerance. Tolerance means tolerance, respect, acceptance and correct understanding of the rich diversity of cultures in our world, our forms of selfexpression and ways of manifesting human individuality. It is promoted by knowledge, openness, communication and freedom of thought, conscience and belief. Tolerance is harmony in diversity (Declaration of Principles on Tolerance, approved on November 16, 1995).

Thanks to a consistent policy of ethnic tolerance, there were no ethnic conflicts in Kazakhstan. Ethnic tolerance is one of the forms of ethics of non-violence. In his speech at the II Congress of Leaders of World and Traditional Religions, Nazarbayev N, et al. [2] noted that modern politicians have forgotten about the religious principle of "non-violence", which allows solving urgent political problems. The fact that 130 ethnic groups and over 40 confessions coexist peacefully in Kazakhstan testifies to the enormous potential of this principle. Having renounced nuclear weapons and established friendly relations with neighboring republics, Kazakhstan has won international recognition and gained fame as a leader in ensuring global security.

Nazarbayev N, et al. [2] defined the following postulates as the basis of the Kazakhstani principle of "non-violence":

- Impartiality, rejection of the stereotypes of mutual perception that have developed over the centuries. You cannot build relationships with neighbors based on negative experience of cooperation. In a person, in an ethnos, one must strive to see positive features and build good-neighborly relations on the basis of this.

- Conscious refusal to invade other people's sacred spheres. What is sacred for one cannot be the subject of humor and ridicule for another. The Constitution of the Republic of Kazakhstan prohibits the media from mocking the feelings of believers

- Awareness of the new threat and the need for a collective response of all world religions to the challenges of our time. The new threat lies in the rational denial of the type of spirituality that all world religions have been developing for millennia.

Thus, the proclaimed tenets of the ethics of nonviolence are expressed in the principles of tolerance and understanding, were born in peaceful conditions and serve the cause of peace and harmony. This is the fundamental difference between the ethics of nonviolence N. Nazarbayev from the ethics of nonviolence M. Gandhi and M.L. King. Ethics of Nazarbayev N, et al. [2] shows how abstract philosophical truths can be successfully applied in practice, overcoming the monstrous gap between speculative metaphysical theories and seething passions of reality [4].

\section{References}

1. Kosichenko A (2010) Kazakhstan experience of tolerance. Kazakhstanskaya Pravda.

2. Nazarbayev N (2007) A word to the people.

3. Tsepkova KB (2010) Realities and myths of Kazakhstani religious tolerance-Materials of the international scientific conference: "Freedom of religion and democracy: old and new challenges".

4. Gardariki M (2007) Ethics.

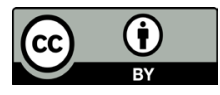

